\title{
Determination of molecular weights of caprine milk proteins by matrix-assisted laser desorption/ionization mass spectrometry
}

\author{
J.-S. Ham, ${ }^{*}$ G.-S. Han, ${ }^{*}$ S.-G. Jeong, ${ }^{*}$ K.-H. Seol, ${ }^{*}$ A.-R. Jang, ${ }^{*}$ M.-H. Oh, ${ }^{*}$ D.-H. Kim, ${ }^{*}$ and Y. W. Park ${ }^{1}$ \\ *Animal Products Research and Development Division, National Institute of Animal Science, Rural Development Administration (RDA), Suwon, \\ Gyeonggi 441-706, Republic of Korea \\ †Agricultural Research Station, Fort Valley State University, Fort Valley, GA 31030-4313
}

\begin{abstract}
Molecular weights (MW) of major proteins in milk of 3 Korean dairy goat breeds were determined by matrixassisted laser desorption/ionization time-of-flight mass spectrometry, after treatment of milk samples with the reduction buffer used in capillary electrophoresis. The MW of caprine milk proteins were compared with those of Holstein milk counterparts using commercial bovine milk protein standards. The MW of $\alpha$-lactalbumin, $\beta$-lactoglobulin, and $\alpha$ - and $\beta$-casein standards were $14,197 \pm 3.4,18,326 \pm 26.3,23,591 \pm 13.0$, and 23,967 $\pm 12.8 \mathrm{~m} / z$, respectively, whereas those of Holstein milk treated with the reduction buffer were 14,199 \pm $8.3,18,397 \pm 25.9,23,614 \pm 64.8$, and $23,984 \pm 75.6$ $\mathrm{m} / z$, respectively. The respective MW of $\alpha$-lactalbumin in Saanen, Toggenberg, and Alpine milk were 14,194 $\pm 27.2,14,266 \pm 105.9$, and $14,241 \pm 13.2 \mathrm{~m} / z$, which were not different from those of the bovine milk. The respective MW of $\beta$ - lactoglobulin in corresponding caprine milk were $18,840 \pm 31.5,18,856 \pm 26.3$, and $18,857 \pm 21.3 \mathrm{~m} / z$, which were higher than those in the bovine milk. The MW of $\beta$-casein in corresponding caprine milk were $23,860 \pm 27.2,23,886 \pm 12.3$, and 23,901 $\pm 8.4 \mathrm{~m} / z$, which were lower than those in the bovine milk. The results indicated that matrix-assisted laser desorption/ionization time-of-flight mass spectrometry could be used for rapid determination of MW of Korean caprine milk proteins without protein separation steps. Key words: molecular weight, caprine, milk protein, matrix-assisted laser desorption/ionization time-offlight
\end{abstract}

\section{INTRODUCTION}

Matrix-assisted laser desorption/ionization (MALDI) is a soft-ionization technique that provides

Received May 17, 2011.

Accepted September 17, 2011.

${ }^{1}$ Corresponding author: parky@fvsu.edu intact molecular ions in the gas phase. Ionization by MALDI produces predominantly single-charged ions, which enables relatively easy data analysis (Carr and Annan, 1996). The MALDI analysis technique uses a low-molecular weight (MW), UV-absorbing organic acid as a matrix to facilitate desorption and ionization of the molecule of interest (Soeryapranata et al., 2002). Matrix-assisted laser desorption/ionization is linked to a time-of-flight (TOF) mass spectrometer of mass determination. The greatest advantage of the MALDI method is that its analysis can be done within a few minutes with sensitivity in the picomole range (Abell and Sporns, 1996).

The introduction of new ionization techniques such as ${ }^{212} \mathrm{Cf}$ plasma desorption (Sundqvist and Macfarlane, 1985; Lacey and Keough, 1989), fast atom bombardment (Biemann et al., 1986; Barber and Green, 1987), electrospray ionization (Covey et al., 1988; Fenn et al., 1989; Henry et al., 1989; Smith et al., 1990), and matrixassisted laser desorption (Karas and Hillenkamp, 1988; Karas et al., 1989; Salehpour et al., 1989) has raised the possibility of using mass spectrometry as an alternative technique for determining the molecular masses of proteins (or protein subunits) in complex mixtures with a much higher accuracy than SDS-PAGE.

The capabilities of MALDI mass spectrometry (MALDI/MS) in the dairy industry were demonstrated by Catinella et al. (1996). A series of analyses were devoted to industrial milk treatment, studying possible thermal damage occurring during milk pasteurization and sterilization. However, $\beta$-LG $(18,381 \pm 10)$ was the highest abundant protein present in the MALDI spectra of raw milk diluted with $0.1 \%$ trifluoroacetic acid (TFA) after centrifugation and drying under a nitrogen stream. Cozzolino et al. (2001) described an analytical method aimed at evaluating both the presence of cow milk in either raw ewe and water buffalo milk samples used in industrial processing and the addition of powdered milk to samples of fresh raw milk using MALDI-TOF/MS. In this method, milk samples were diluted to $1: 100$ ( $\mathrm{vol} / \mathrm{vol}$ ) with $0.1 \%$ TFA. They noted the decreases in the intensity of $\mathrm{CN}$ mass signals 
and assumed the cause to be precipitation of those polypeptides by TFA solution.

Due to the problem of the decreased intensity of $\mathrm{CN}$ mass signals with the TFA reagent, the utility of the MALDI technique may be limited in determination of MW of polypeptides. An alternative or improved sample preparation method would be desirable to increase the intensity of mass signals for high-MW proteins such as CN. We hypothesized that the reduction buffer extraction method of bovine milk used in capillary electrophoresis analysis (Ham et al., 2010) before the $0.1 \%$ TFA dilution procedure would increase the intensity of mass signals of $\mathrm{CN}$ in the MALDI analysis for determination of their MW.

The MALDI-TOF mass spectrometry method could have a major advantage over column chromatography or electrophoretic methods, as it can quantify MW of milk proteins without tedious protein separation steps from a milk sample. Molecular weights of bovine milk proteins have been extensively studied (Alais, 1984; Ribadeau-Dumas and Grappin, 1989; Swaisgood, 1993), whereas those of caprine milk counterparts have not been well defined. In addition, most reports on caprine milk proteins have been based on electrophoretic and HPLC methods.

The objective of our study, therefore, was to investigate the feasibility of increasing the accuracy of MALDI-TOF analysis in determination of MW of major proteins in the milk of 3 Korean dairy goat breeds by using the reduction buffer of capillary electrophoresis before the TFA dilution procedure in the preparation of samples for MALDI-TOF analysis.

\section{MATERIALS AND METHODS}

\section{Preparation of Milk Samples}

Caprine milk samples were taken from Saanen, Toggenberg, and Alpine goats in a dairy goat farm located at Chungcheong Province, South Korea. Holstein cow milk was obtained from the bulk tank of an experimental farm in the National Institute of Animal Science (NIAS), Suwon, Korea. Milk samples were transported under refrigeration to the laboratories of NIAS.

\section{Preparation of Chemicals and Reagents}

Sodium hydroxide (analytical grade) was purchased from Junsei Chemical Co. Ltd. (Tokyo, Japan). Acetonitrile, TFA, dithiothreitol (DTT), urea, $\alpha-\mathrm{LA}, \beta-\mathrm{LG}$, and CN standards were purchased from Sigma Chemical Co. (St. Louis, MO). Trisodium citrate dihydrate was obtained from the Merck KGaA (Darmstadt, Ger- many). Sinapinic acid and protein calibration standard I (mixture of insulin, cytochrome C, myoglobin, ubiquitin $\mathrm{I}$, and cytochrome $\mathrm{C}$ ) was purchased from Bruker Daltonik GmbH (Bremen, Germany). All reagents were prepared with double deionized water using the Milli-Q system (Millipore Corp., Bedford, MA).

The reduction buffer of capillary electrophoresis was prepared by dissolving $73 \mathrm{mg}$ of trisodium citrate dehydrate and $38 \mathrm{mg}$ of DL-DTT in $37.5 \mathrm{~mL}$ of $8 M$ urea. The $\mathrm{pH}$ was adjusted to 8.0 with dilute sodium hydroxide solution in a $50 \mathrm{~mL}$ volumetric flask and made up to volume with deionized water.

\section{Mass Spectrometry}

MALDI Instrument. The MALDI measurements were performed on a microflex TOF mass spectrometer (Bruker Daltonik GmbH). The instruments are fitted with a pulsed nitrogen laser $(337 \mathrm{~nm})$ with a 3 -ns pulse duration.

Treatment of Milk Samples for MALDI Analysis. All milk samples were treated as follows: a $0.5-\mathrm{mL}$ milk sample was diluted with $2.5 \mathrm{~mL}$ of the reduction buffer and incubated for $1 \mathrm{~h}$ at room temperature $\left(25^{\circ} \mathrm{C}\right)$, and the resulting clear solution was diluted 1:100 (vol/vol) with $0.1 \%$ TFA. A $10-\mu \mathrm{L}$ sample of cow milk was diluted 1:100 (vol/vol) with $0.1 \%$ TFA for comparison. For milk protein standards, $0.2 \mathrm{~g}$ each of $\alpha$-LA; $\beta$-lactoglobulin; and $\alpha-, \beta-$, and $\kappa-\mathrm{CN}$ (Sigma Chemical Co.) was dissolved in $10 \mathrm{~mL}$ of Milli-Q water and diluted 1:100 (vol/vol) with $0.1 \%$ TFA.

For all of the MALDI spectra, sinapinic acid, as a saturated solution in acetonitrile-water (1:1, vol/vol), was used as a matrix. Five microliters of the sample solution was added to $5 \mu \mathrm{L}$ of the matrix solution and $1 \mu \mathrm{L}$ of the resulting mixture was deposited on the sample target and allowed to dry at room temperature $\left(25^{\circ} \mathrm{C}\right)$. Three independent measurements were made for each sample to verify the reproducibility and the mass accuracy, which was always within the range 0.5 to $1.0 \%$. External mass calibration, carried out daily, was performed using protein calibration standard I (Bruker Daltonik GmbH).

\section{Statistical Analysis}

All experimental data were statistically analyzed by the SAS Enterprise Guide (SAS Institute, 2006). The Student $t$-test was performed to compare the differences in levels of molecular weights of 5 proteins between goat and cow milks, and Duncan's multiple-range test was performed if differences were identified between the groups at $P<0.05$. 


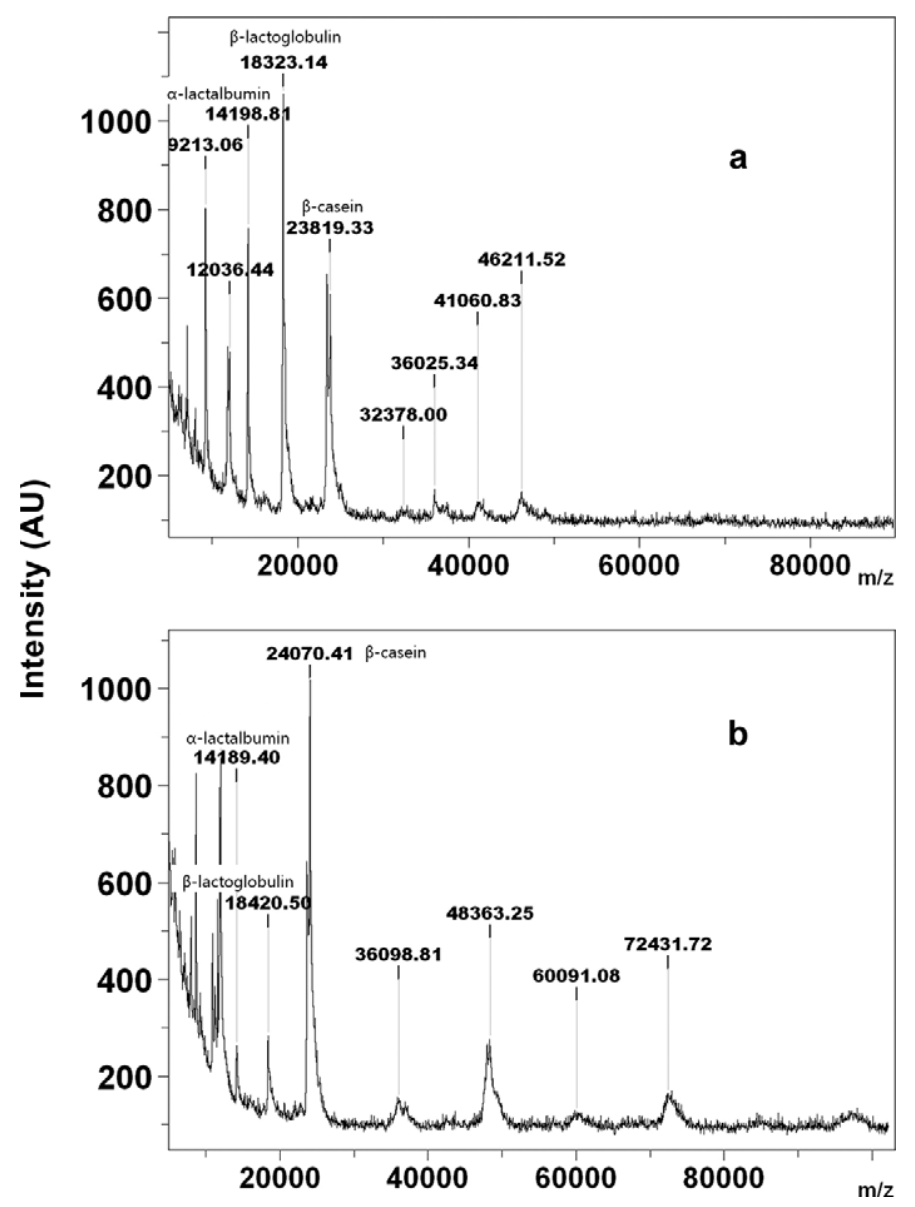

Figure 1. Typical matrix-assisted laser desorption/ionization (MALDI) spectra of bovine milk: (a) direct dilution with $0.1 \%$ trifluoroacetic acid (TFA) and (b) dilution with $0.1 \%$ TFA after treatment with reduction buffer.

\section{RESULTS AND DISCUSSION}

The characteristics of the MALDI spectra of bovine milk proteins in the sample prepared with $0.1 \%$ TFA only compared with those of the MALDI spectra in the sample prepared with $0.1 \%$ TFA in addition to the reduction buffer treatment are shown in Figure 1. Relative peak size in the range of 22,000 to approximately $26,000 \mathrm{~m} / z$ was much larger for the reduction buffer-treated (Figure 1b) bovine milk than that for the sample prepared in $0.1 \%$ TFA only (Figure 1a). Our results showed that the intensities of the peaks have been increased to almost double for samples treated with reduction buffer, compared with those without the reduction buffer treatment. These results demonstrate that our hypothesis has been proven right, where the application of the reduction buffer from capillary electrophoresis can increase or improve the intensities of CN peaks for MALDI-TOF analysis in more accurate quantification of the proteins.

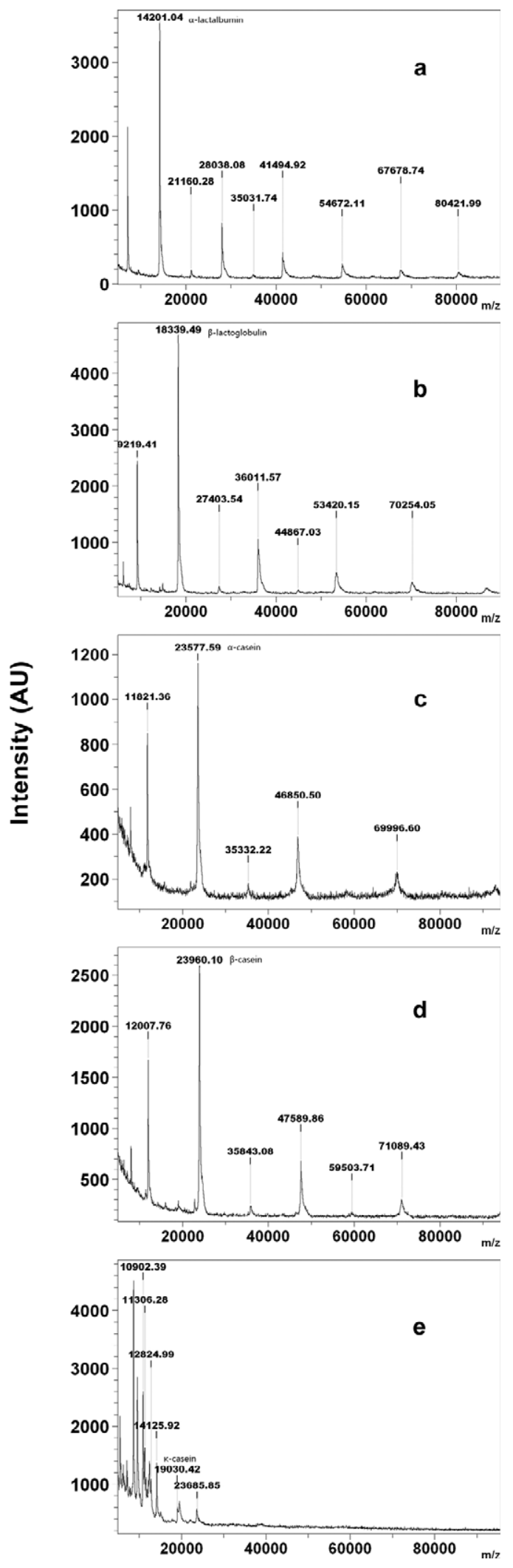

Figure 2. Typical matrix-assisted laser desorption/ionization (MALDI) spectra of bovine milk protein standards (a: $\alpha-L A ; b: \beta-L G$; c: $\alpha-\mathrm{CN} ; \mathrm{d}: \beta-\mathrm{CN}$; and e: $\kappa-\mathrm{CN})$. 
Table 1. Molecular weights (means \pm SD) of protein in standard and in reduction buffer-treated milk

\begin{tabular}{lcccc}
\hline & & & \multicolumn{2}{c}{ Source from the literature } \\
\cline { 4 - 5 } $\begin{array}{l}\text { Milk } \\
\text { protein }\end{array}$ & $\begin{array}{c}\text { Standard } \\
(\mathrm{m} / z)\end{array}$ & $\begin{array}{c}\text { Buffer-treated } \\
\text { cow milk }(m / z)\end{array}$ & Alais $(1984)$ & Swaisgood $(1993)$ \\
\hline$\alpha$-LA & $14,197 \pm 3.4$ & $14,199 \pm 8.3$ & 14,200 & \\
$\beta$-LG & $18,326 \pm 26.3$ & $18,397 \pm 25.9^{*}$ & 18,360 & \\
& & & $36,000($ dimer $)$ & \\
$\alpha_{\mathrm{s}}$-CN & $23,591 \pm 13.0$ & $23,614 \pm 64.8$ & $23,600\left(\alpha_{\mathrm{s} 1}-\mathrm{CN}\right)$ & $23,623\left(\alpha_{\mathrm{s} 1}-\mathrm{CN}\right)$ \\
$\beta$-CN & $23,967 \pm 12.8$ & $23,984 \pm 75.6$ & 24,000 & 23,988 \\
$\kappa$-CN & $19,046 \pm 12.8$ & & 19,000 & 19,006 \\
& $19,517 \pm 32.7$ & & & \\
$* P<0.05$ & & & &
\end{tabular}

$* P<0.05$.

Considering the MW and composition of $\mathrm{CN}$ in milk in the literature, MALDI spectra of the reduction buffer-treated samples are more reasonable than those of non-treated ones. The reports in MALDI spectra by Catinella et al. (1996) and Cozzolino et al. (2001) showed similar profiles to Figure 1a, which may limit the use of MALDI-TOF methods in quantitative detection of CN in milk samples. Cozzolino et al. (2001) reported that the use of TFA reagent decreased the intensity of CN mass signals, probably attributed to a slight precipitation of these polypeptides.

Commercial bovine milk protein standards were analyzed without reduction buffer treatment to compare the efficiency of reduction buffer on determination of MW (Figure 2). Molecular weights of major peaks of all of the proteins except $\kappa-\mathrm{CN}$ are summarized and compared in Table 1 . The quality of $\kappa-\mathrm{CN}$ spectrum is lower than those of the other proteins, due to the presence of a rather large number of impurities. Therefore, instead of selecting a major peak, the peaks similar to the value of previous reports (Alais, 1984; Swaisgood, 1993) were selected and compared. The $\mathrm{k}-\mathrm{CN}$ peak in reduction buffer-treated milk could not be detected because of the relative abundance of the $\beta-\mathrm{LG}$ peak. The MW of the $\beta$-LG standard treated with TFA only was significantly $(P<0.05)$ lower than that of the additional reduction buffer-treated bovine milk $(\mathrm{m} / z$ $18,326 \pm 26.3$ vs. $m / z 18,397 \pm 25.9$; Table 1 ), whereas no differences were found for those of $\alpha-\mathrm{LA}, \alpha-\mathrm{CN}$, and $\beta-\mathrm{CN}$.

Molecular weights of caprine milk proteins were measured, and typical MALDI spectra were shown in Figure 3. $\alpha$-Lactalbumin, $\beta$-LG, and $\beta$-CN peaks were identified according to bovine milk standards and the MW were compared with those of reduction buffer-treated bovine milk (Table 2). The MW of $\alpha-\mathrm{LA}$ in Saanen, Toggenberg, and Alpine caprine milk was $14,194 \pm$ $27.2,14,266 \pm 105.9$, and $14,241 \pm 13.2 \mathrm{~m} / z$, respectively, and did not show significant difference from that of bovine milk. However, the MW of $\beta-\mathrm{LG}$ and $\beta-\mathrm{CN}$ in caprine milk were different from those in bovine milk. The MW of $\beta$-LG in Saanen, Togenberg, and Alpine caprine milk was $18,840 \pm 31.5,18,856 \pm 26.3$, and $18,857 \pm 21.3 \mathrm{~m} / z$, respectively, and was larger $(P<$ $0.05)$ than that of bovine milk. However, the MW of $\beta-\mathrm{CN}$ in Saanen, Togenberg, and Alpine caprine milk was $23,860 \pm 27.2,23,886 \pm 12.3$, and $23,901 \pm 8.4$ $\mathrm{m} / z$, respectively, which was smaller $(P<0.05)$ than that in bovine milk.

\section{CONCLUSIONS}

Molecular weights of major proteins in goat milks were determined by MALDI mass spectrometry after reduction buffer extraction (used in capillary electrophoresis) and were compared with those in cow milk. Major proteins in reduction buffer-treated cow milk were identified by comparing to commercial milk protein standards. The MW of $\beta-L G$ in Saanen, Toggenberg, and Alpine caprine milk was larger than that in bovine milk, whereas those of $\beta-\mathrm{CN}$ were smaller. Differences in MW among the breeds were not significant. Because the results of this study showed that it is feasible that the intensity of CN mass signals can be increased or enhanced by reduction buffer treatment, further investigation on milk from large-scale goat herds or other species is needed for the applicability of this modified procedure of the MALDI technique for practical application.

Table 2. Molecular weights (means $\pm \mathrm{SD}$ ) of major proteins in cow and goat milk

\begin{tabular}{lcccc}
\hline $\begin{array}{l}\text { Milk } \\
\text { protein }\end{array}$ & $\begin{array}{c}\text { Cow milk } \\
(m / z)\end{array}$ & $\begin{array}{c}\text { Saanen } \\
\text { milk }(m / z)\end{array}$ & $\begin{array}{c}\text { Toggenberg } \\
\text { milk }(m / z)\end{array}$ & $\begin{array}{c}\text { Alpine } \\
\text { milk }(m / z)\end{array}$ \\
\hline$\alpha-\mathrm{LA}$ & $14,199 \pm 8.3^{\mathrm{a}}$ & $14,194 \pm 27.2^{\mathrm{a}}$ & $14,266 \pm 105.9^{\mathrm{a}}$ & $14,241 \pm 13.2^{\mathrm{a}}$ \\
$\beta$-LG & $18,397 \pm 25.9^{\mathrm{b}}$ & $18,840 \pm 31.5^{\mathrm{a}}$ & $18,856 \pm 26.3^{\mathrm{a}}$ & $18,857 \pm 21.3^{\mathrm{a}}$ \\
$\beta$-CN & $23,984 \pm 75.6^{\mathrm{a}}$ & $23,860 \pm 27.2^{\mathrm{b}}$ & $23,886 \pm 12.3^{\mathrm{b}}$ & $23,901 \pm 8.4^{\mathrm{b}}$ \\
\hline
\end{tabular}

${ }^{\mathrm{a}, \mathrm{b}}$ Values with different superscripts in the same row differ significantly $(P<0.05)$. 

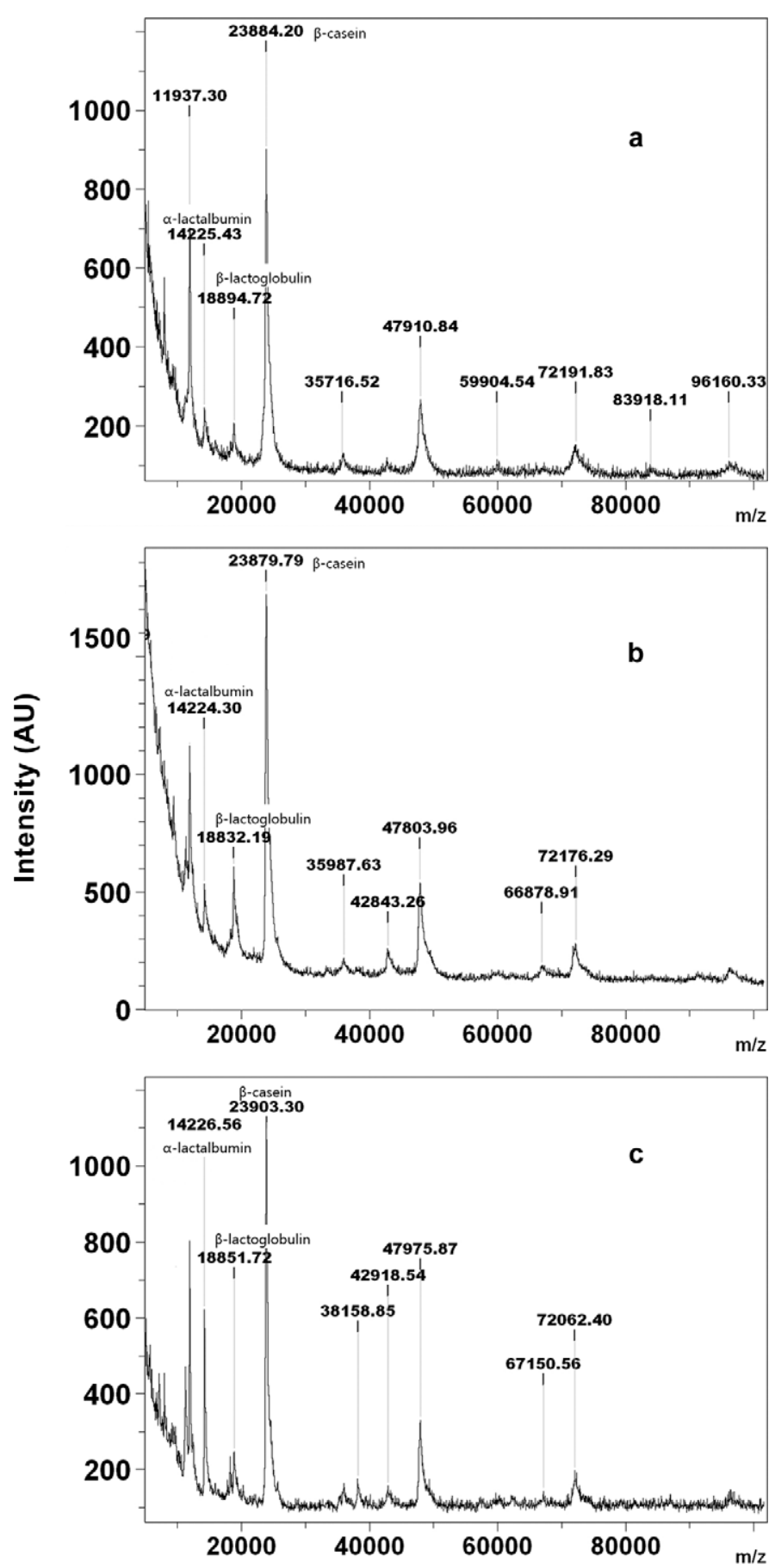

Figure 3. Typical matrix-assisted laser desorption/ionization (MALDI) spectra of cow milk protein standards (a: Saanen; b: Toggenberg; and c: Alpine).

\section{ACKNOWLEDGMENTS}

This study was supported by the funding of the Rural Development Administration (RDA, Suwon, Gyeonggi, Korea) Bio-Green project (PJ007186082011).

\section{REFERENCES}

Abell, D. C., and P. Sporns. 1996. Rapid quantitation of potato glycoalkaloids by matrix-assisted laser desorption/ionization time-offlight mass spectrometry. J. Agric. Food Chem. 44:2292-2296.

Alais, C. 1984. Scienza del latte. Tecniche Nuove, Milano, Italy.

Barber, M., and B. N. Green. 1987. The analysis of small proteins in the molecular weight range $10-24 \mathrm{kDa}$ by magnetic sector mass spectrometry. Rapid Commun. Mass Spectrom. 1:80-83.

Biemann, K., S. A. Martin, H. A. Scoble, R. S. Johnson, I. A. Papayanopoulos, J. E. Biller, and C. E. Costello. 1986. How to obtain and how to use mass spectral data at high mass. Pages 131-149 in Mass Spectrometry in the Analysis of Large Molecules. C. J. McNeal, ed. Wiley, Chichester, UK.

Carr, S. A., and R. S. Annan. 1996. Overview of peptide and protein analysis by mass spectrometry. Pages $16.1 .1-27$ in Current Protocols in Protein Science. J. E. Coligan, ed. John Wiley \& Sons, Brooklyn, NY.

Catinella, S., P. Traldi, C. Pinelli, E. Dallaturca, and R. Marsilio. 1996. Matrix-assisted laser desorption/ionization mass spectrometry in milk science. Rapid Commun. Mass Spectrom. 10:1629-1637.

Covey, T. R., R. F. Bonner, B. I. Shushan, and J. D. Henion. 1988 The determination of protein, oligonucleotide and peptide molecular weights by ion-spray mass spectrometry. Rapid Commun. Mass Spectrom. 2:249-256.

Cozzolino, R., S. Passalacqua, S. Salemi, P. Malvagna, E. Spina, and D. Garozzo. 2001. Identification of adulteration in milk by matrixassisted laser desorption/ionization time-of-flight mass spectrometry. J. Mass Spectrom. 36:1031-1037.

Fenn, J. B., M. Mann, C. K. Meng, S. F. Wong, and C. M. Whitehouse. 1989. Electrospray ionization for mass spectrometry of large biomolecules. Science 246:64-71.

Ham, J.-S., S.-G. Lee, S.-G. Jeong, M.-H. Oh, D.-H. Kim, and Y. W. Park. 2010. Characteristics of Korean-Saanen goat milk caseins and somatic cell counts in comparison with Holstein cow milk counterparts. Small Rumin. Res. 93:202-205.

Henry, K. D., E. R. Williams, B. H. Wang, F. W. McLafferty, J. Shabanowitz, and D. F. Hunt. 1989. Fourier-transform mass spectrometry of large molecules by electrospray ionization. Proc. Natl. Acad. Sci. USA 86:9075-9078.

Karas, M., U. Bahr, and F. Hillenkamp. 1989. UV laser matrix desorption/ionization mass spectrometry of proteins in the 100,000 dalton range. Int. J. Mass Spectrom. Ion Process. 92:231-242.

Karas, M., and F. Hillenkamp. 1988. Laser desorption ionization of proteins with molecular masses exceeding 10,000 daltons. Anal. Chem. 60:2299-2301.

Lacey, M. P., and T. Keough. 1989. Plasma-desorption mass spectrometry of intact enzymes and proenzymes. Rapid Commun. Mass Spectrom. 3:323-328.

Ribadeau-Dumas, B., and R. Grappin. 1989. Milk protein analysis. Lait 69:357-416.

Salehpour, M., I. Perera, J. Kjellberg, A. Hedin, M. A. Islamian, P. Håkansson, and B. U. R. Sundqvist. 1989. Laser-induced desorption of proteins. Rapid Commun. Mass Spectrom. 3:259-263.

SAS Institute. 2006. SAS Enterprise Guide. Version 4.2. SAS Institute Inc., Cary, NC.

Smith, R. D., J. A. Loo, C. G. Edmonds, C. J. Barinaga, and H. R. Udseth. 1990. New developments in biochemical mass spectrometry: Electrospray ionization. Anal. Chem. 62:882-899.

Soeryapranata, E., J. R. Powers, H. H. Hill Jr., W. E. Siems III, K. A. Al-Saad, and K. M. Weller. 2002. Matrix-assisted laser desorption/ ionization time-of-flight mass spectrometry method for the quantification of $\beta$-casein fragment (f193-209). J. Food Sci. 67:534-538.

Sundqvist, B., and R. D. Macfarlane. 1985. ${ }^{252}$ Cf-Plasma desorption mass spectrometry. Mass Spectrom. Rev. 4:421-460.

Swaisgood, H. E. 1993. Review and update of casein chemistry. J. Dairy Sci. 76:3054-3061. 